\title{
A family with Alport's syndrome
}

\author{
P. JAIN * \\ B.Sc., M.B., M.R.C.P. (Lond. Edin. \& Glasgow) \\ Senior Medical Registrar, Derbyshire Royal Infirmary, Derby
}

\begin{abstract}
Summary
Alport's syndrome has been diagnosed in members of four successive generations of one family.

Renal biopsy was performed in two of these patients. The syndrome is briefly reviewed.
\end{abstract}

\section{Introduction}

Alport's syndrome (hereditary nephritis and deafness) is an uncommon disease and only a few cases have been described in this country. It was described by Alport (1927) and recently the original family which he studied has been traced (Crawfurd \& Toghill, 1968) (Fig. 1).

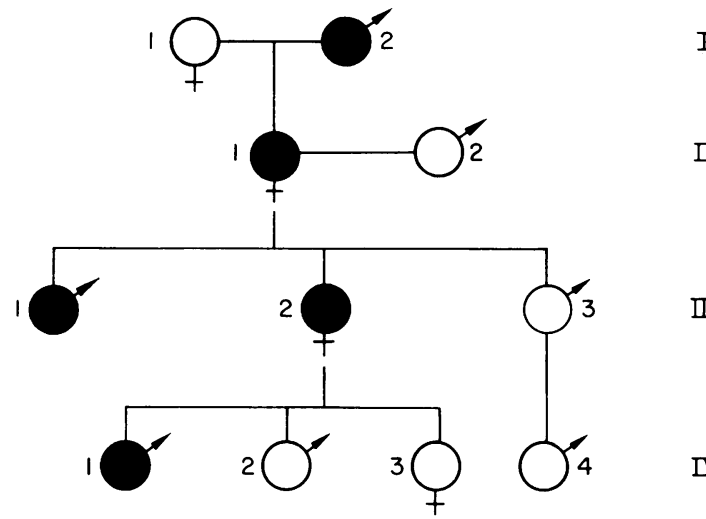

FIG. 1. Family tree. Affected members.

\section{Case No. IV 1}

This boy who is now 14 years old was first seen in January 1959 at Derbyshire Children's Hospital with a history of recurrent haematuria. There was no frequency or dysuria and routine physical examination did not reveal any abnormality.

\section{Investigations}

$\mathrm{Hb} 76 \%$, ESR $5 \mathrm{~mm}$ (Westergren), WBC 9800 $\mathrm{mm}^{3}$, platelets $192,000 \mathrm{~mm}^{3}$, blood urea $26 \mathrm{mg} /$ $100 \mathrm{ml}$, bleeding time $2 \frac{1}{2} \mathrm{~min}$, clotting time $3 \mathrm{~min}$, no excess of oxalic acid in urine. Urine showed no

\footnotetext{
* Present address: St Mary Abbot's Hospital, London, W.8.
}

albumin, RBC 15 per high power field, WBC 1 per high power field, scanty granular casts and no growth on culture.

No specific treatment was given and his haematuria subsided spontaneously.

$\mathrm{He}$ has been regularly seen since then. $\mathrm{He}$ is still getting intermittent attacks of haematuria lasting 2-3 days every 2-3 months. The degree of haematuria varies from microscopic to frank blood in the urine. When last seen in January 1969, the urine contained a moderate amount of albumin with many red cells but no casts. The blood urea was $28 \mathrm{mg} / 100 \mathrm{ml}$. His hearing is defective and he wears a hearing aid. Audiometry examination shows perceptive deafness.

Renal biopsy (Hospital for Sick Children, Great Ormond Street, London).

Report. Two-micron thick sections were prepared and these contain an average of fourteen glomeruli as well as a fragment of medullary tissue. Five of these fourteen glomeruli show diffuse, non-segmental, proliferative change of capillary endothelial cells, almost completely filling the capsular space, with accompanying slight fibrous thickening of Bowman's Capsule. The other glomeruli are within normal limits. A few tubules contain granular casts. These histological changes suggest the diagnosis of focal, non-segmental glomerulonephritis.

Histological diagnosis. Suggestion of focal nonsegmental glomerulonephritis.

\section{Case No. III 2}

The mother of IV 1. She has been the main informant about the family. She is a trained staff nurse and has been very helpful with her family medical history. She was first seen in 1961 at Derbyshire Royal Infirmary when aged 28 years on account of a feeling of tiredness. She had nephritis when aged 6 years and was later found to have albumin in the urine during routine medical examination at the age of 17. Toxaemia occurred in two previous pregnancies. Routine physical examination was normal. 


\section{Investigations}

Haemoglobin $102 \%$, blood urea $24 \mathrm{mg} / 100 \mathrm{ml}$. Urine, a moderate amount of albumin, many RB and WBC. Culture yielded a growth of Escherichia coli.

She was treated with nitrofurantoin. She reported feeling better, so much so that she stopped attending the clinic.

She was next seen 5 years later in November 1966 with a history of tiredness and headache. Since her last visit, another pregnancy had occurred which was also associated with toxaemia. Her blood pressure had now risen to $160 / 110 \mathrm{mmHg}$, blood urea to $60 \mathrm{mg} / 100 \mathrm{ml}$ and ESR to $39 \mathrm{~mm} / \mathrm{hr}$. The haemoglobin had fallen to $78 \%$. The urine showed a moderate amount of albumin with many red cells and a few leucocytes, but no growth on culture. An intravenous pyelogram was normal.

She has since been seen regularly. Currently, her main complaint is tiredness. Her blood pressure is $170 / 100$ on methoserpidine $5 \mathrm{mg}$ t.d.s. Chest X-ray and ECG normal, $\mathrm{Hb} 11.0 \mathrm{~g} / 100 \mathrm{ml}$, ESR $77 \mathrm{~mm} / \mathrm{hr}$, blood urea $126 \mathrm{mg} / 100 \mathrm{ml}$ (on Giovanetti diet), MSU, moderate amount of albumin with a fair number of red cells. No growth on culture. Although her hearing is normal, audiogram shows perceptive deafness with a loss of 20-40 decibels at frequencies of 3000 cycles.

Renal biopsy (Done at Derbyshire Royal Infirmary by Dr H. L. Matthews).

Report (Dr Cocker). Two small fragments of renal cortex in which four glomeruli are visualized. There is a patchy interstitial fibrosis containing lymphocytes and atrophic tubules. An area of normal appearing tubules is adjacent. One glomeruli is a hyaline scar, another shows periglomerular fibrosis, the third proliferation and thickening of the mesangium with a little thickening of the basement membrane, the fourth is normal. The kidney is abnormal but the biopsy is too small to be dogmatic about the diagnosis. However, the changes seen are in keeping with those described in hereditary nephritis (Fig. 2).

\section{Case No. III 1}

Brother of III 2 was admitted to Derby City Hospital in October 1955 at the age of 16 . He was found to be completely deaf with defective vision and in advanced uraemia.

\section{Investigations}

$\mathrm{Hb} 40 \%$, WBC $19,250 \mathrm{~mm}^{3}$, bleeding time 9 min. Prothrombin time $23 \mathrm{sec}$ (normal $17 \mathrm{sec}$ ), blood urea $480 \mathrm{mg} / 100 \mathrm{ml}$ serum sodium 128 , chloride 125 and potassium $6.5 \mathrm{mEq} / 1$. Plasma bicarbonate $5.0 \mathrm{mEq} / 1$. Urine: acid, many $\mathrm{RBC}$, amorphous urates, albumin ++ .

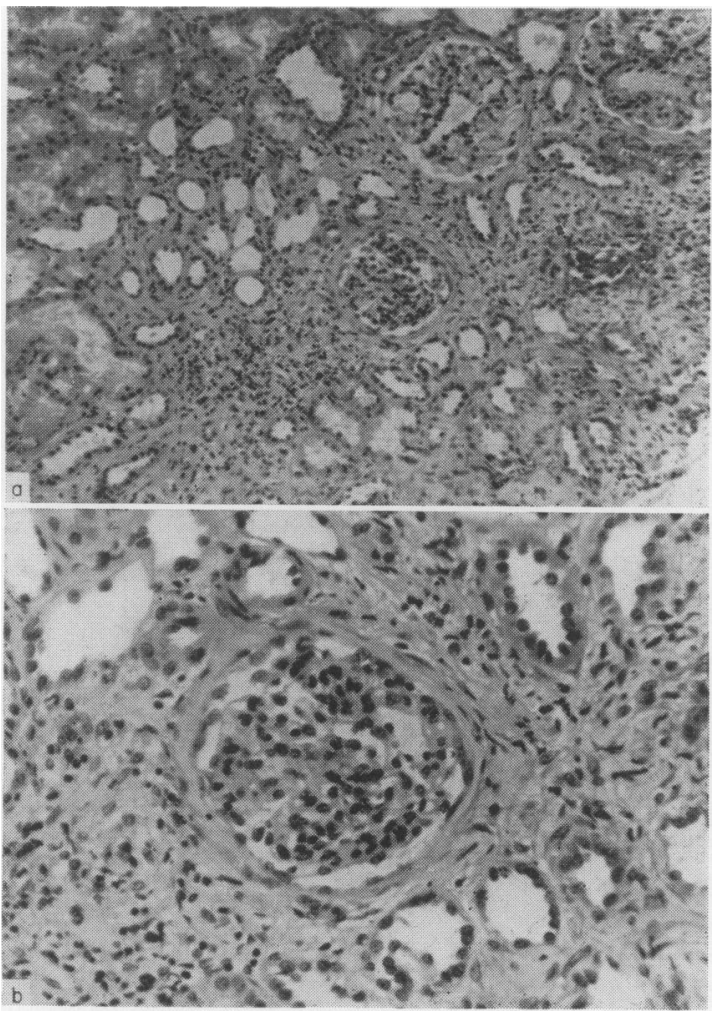

FIG. 2. (a) $\times 88$. (b) Higher magnification of (a) $\times 300$.

He died a few days later. No necropsy was carried out.

Not much is known about his previous illness. He was a stubborn child and did not like seeing doctors or following their advice. Apparently, he had been having recurrent haematuria since 1947 when he was only 8 years old. It was said that he always looked waxy and was thought to be mentally slow.

\section{Case No. III 3}

Brother of III 1 and 2; now 37 years old. He has always been fit and healthy but in May 1968, he had an episode of haematuria. Routine physical examination was normal.

\section{Investigations}

Hb $14.2 \mathrm{~g} / 100 \mathrm{ml}$, blood urea $28 \mathrm{mg} / 100 \mathrm{ml}$, MSU many red cells, no casts and no growth on culture. Intravenous pyelogram showed renal stone.

His hearing is normal. An audiometry was requested but the patient failed to turn up.

Haematuria subsided spontaneously and has not recurred. It is possible that his episode of haematuria was due to a renal stone, unrelated to the family condition. 
Case No. II 1

Mother of III 1, 2 and 3; died of uraemia in 1940, aged 31 years. She had toxaemia of pregnancy while carrying III 1. Her hearing was normal. She was seen at Leek Memorial Hospital, Stoke-on-Trent but detailed information is not available as all notes have been destroyed.

\section{Case No. I 2}

Father of II 1; also died of uraemia in 1951 aged 53 at Leek Memorial Hospital, Stoke-on-Trent. Unfortunately, his notes cannot be traced either.

\section{Cases Nos. IV 2 and 3}

Children of III 2 and IV 4 son of III 3 are all healthy normal children. Physical and laboratory examinations are quite normal. Audiometry examinations, however, have not been carried out.

\section{Discussion}

Four generations of an English family suffering from hereditary nephritis are described. The nephritis is often associated with deafness, when the condition is called 'Alport's syndrome'. In cases where deafness is not obvious, audiometry examination has often been found to be abnormal. In the family described here, case numbers IV 1 and III I have obvious hearing loss while case number III 2 has normal hearing but abnormal audiometry with changes of perceptive deafness. Although deafness is usually associated with a renal lesion, it may occur as the only manifestation of the disease in otherwise unaffected members of the family. It is an essential part of the syndrome and Hurst was the first to call attention to it. According to Crawfurd $\&$ Toghill (1968), it is most likely 'due to a metabolic defect leading to progressive damage of the epithelial tissues of highly specialised function'. Besides deafness, various ocular defects, such as lenticonus and spherophakia, have been described (Arnott, Crawfurd \& Toghill, 1966). The only patient in this family who apparently had an ocular defect was III 1 but exact details are not available since the patient died only a few days after admission in uraemia.

The mode of transmission in Alport's syndrome is by either a simple autosomal dominant (Howe \& Smythe, 1962) or partial sex linkage (Perkoff et al., 1951). Both sexes are involved. However, in males the disease is much more severe and most affected male members reported in the literature have died before they reach 30 years of age (Goldman \& Haberfeld, 1959). In affected females, the prognosis is better, many of them having a normal life-span.
They are, however, very prone to toxaemia of pregnancy as is evidenced in case numbers III 2 and II 1.

Histologically, in the majority of cases two kinds of lesions have been described in the kidney, those of chronic glomerulonephritis (Gutherie, 1902; Alport, 1927) and chronic pyelonephritis (Perkoff et al., 1951). It is not clear, however, whether pyelonephritis is primary or superimposed upon the underlying renal lesion. In some series a high frequency of lipid-staining foam cells have been reported (Perkoff et al., 1958). These are, however, not present in every case and have also been described in other conditions (Whalden et al., 1961). According to Kricksten, Gloor \& Balogh (1966), the renal changes in Alport's syndrome combine the features of chronic glomerulonephritis, pyelonephritis and interstitial nephritis.

The two renal biopsies reported here show similar changes.

\section{Acknowledgments}

I am indebted to Dr E. J. S. Woolley for allowing me to study his patients and to Dr H. L. Matthews for his help with the manuscript and for performing the renal biopsy on Case No. 2.

\section{References}

AlPORT, A.C. (1927) Hereditary familial congenital haemorragic nephritis. British Medical Journal, 1, 504.

Arnott, E.J., Crawfurd, M.D'A. \& Togh!ll, P.J. (1966) Anterior lenticonus and Alport's syndrome. British Journal of Ophthalmology, 50, 7.

Crawfurd, M.D'A. \& Toghill, P.J. (1968) Alport's syndrome of hereditary nephritis and deafness. Quarterly Journal of Medicine, 148, 563.

Case records of the Massachusetts General Hospital (1957) Case 43511 New England Journal of Medicine, 257, 1231.

Goldman, R. \& Haberfelde, G.C. (1959) Hereditary nephritis. New England Journal of Medicine, 261, 734.

GUTHRIE, A.C. (1902) 'Idiopathic' or congenital hereditary and family haematuria. Lancet, 1, 1243.

Goldbloom, R.B., Fraser, F.C., Waugh, D., Arnovitch, M. \& WIGLeSWORTH, F.H. (1957) Hereditary Renal disease associated with nerve deafness and ocular lesion. Pediatrics, 20, 241.

HuRst, A.F. (1923) Hereditary familial congenital haemorrhagic nephritis. Guy's Hospital Reports, 73, 368.

Howe, H.G., Jr, \& Smythe, C.M. (1962) Hereditary nephropathy associated with nerve deafness and ocular lesion. Clinical Research, 10, 43.

Krickstein, H.I., GloOR, F.J. \& Balogh, K., Jr (1966) Renal pathology in hereditary nephritis with nerve deafness. Archives of Pathology, 82, 506.

Perkoff, G.T., Nugent, C.A., Jr, Dolowitz, D.A., Stephens, F.E., Carnes, W.H. \& TYler, F.H. (1958) A follow up study of hereditary chronic nephritis. Archives of Internal Medicine, 102, 733.

Whalen, R.E., Huang, S., Preschell, E. \& Mcintosh, H.D. (1961) Hereditary nephropathy, deafness and renal foam cells. American Journal of Medicine, 31, 17. 
puter, to be able to follow the course of anaesthesia as opposed to the circulatory or respiratory problems of the patient. I merely throw this in front of you. Now both of these are examples that we are dealing not solely in problems of technology, that is how we are going to do something, but what is it necessary to measure.

Finally we have to consider the courtesies due to those responsible for this symposium. First we have to thank the Wigan and Leigh Hospital Management Committee for sponsoring this conference. Secondly, we have to thank the Royal College of Surgeons for allowing the use of the College premises and facilities. Thirdly, our thanks are due to all the speakers. Our greatest thanks are due to Mr Stewart who has been responsible for the conference from conception to birth and to healthy, vigorous success. We thank you Mr Stewart for without you the symposium would not have been.

Lastly I must thank all the audience for your attendance and patient listening and questioning; without you the symposium would have been as nothing. Thank you and Goodnight to you.

SteWART. Lord Brock, may I just say a word of thanks to Professor Kenedi who was Chairman this morning and to yourself who have so ably chaired the proceedings this afternoon. I believe Sir that this is in fact your birthday and may we offer you our best wishes for many happy returns.

\section{References}

Adgey, A.A.J., Geddes, J.S., Mulholland, H.C., Keegan, D.A.J. \& PANTRIDGE, J.F. (1968) Incidence significance and management of early bradyarrhythmia complicating acute myocardial infarction. Lancet, ii, 1097.

Adgey, A.A.J., Nelson, P.G., Scott, M.E., Geddes, J.S., Allen, J.D., Zaidi, F.A. \& Pantridge, J.F. (1969) Management of ventricular fibrillation outside hospital. Lancet, i, 1169.

Cameron, A.J.V., GibB, B.H., Ledingham, I.MCA., McGuinness, J.B., Norman, J.N. \& Sharif, M. (1964) A controlled clinical trial of hyperbaric oxygen in the treatment of acute myocardial infarction. Preliminary results. Clinical Application of Hyperbaric Oxygen. (Ed. by I. Boerema, W. H. Brummelkamp and N. G. Meijne), pp. 75-83. Elsevier, Amsterdam.

How, E.H. (1958) Electronic evaluation of the foetal heart rate. American Journal of Obstetrics and Gynecology, 74, 1212-1230 and subsequent papers.

LARKS, S.P., WEBSTER, A. \& LARKS, G.G. (1967) Quantitative studies in foetal electrocardiography. American Journal of Obstetrics and Gynecology, 98, 52-55.

Raison, J.C.A., Beaumont, J.O., Russell, J.A.G., Osborn, J.J. \& Gerbode, F. (1968) Alarms in an intensive care unit: an interim compromise. Computers and Biomedical Research, 1, 556.

REPORT (1969) The Inventor, 9, 26. Brussels Exhibition, 1969. StewarT, J.S.S. (1969) Meaningful monitoring. Lancet, i, 1305.

WolfF, H.S. (1968) Patient monitoring in intensive care. Hosrital Medicine, 2, 554.

\author{
Erratum \\ JAIN, P. (1970) A family with Alport's syndrome. \\ Postgraduate Medical Journal, 46, 83. \\ p. 85 , column 1 , line 8 , \\ for aged 53 read aged 63 .
}

